\title{
Building Mathematics Cellular Phone Learning Communities
}

\author{
doi:10.3991/ijim.v5i2.1475 \\ W. Daher \\ Al-Qasemi Academic College of Education, Baka, Israel \& An-Najah National University, Nablus, Palestine
}

\begin{abstract}
Researchers emphasize the importance of maintaining learning communities and environments. This article describes the building and nourishment of a learning community, one comprised of middle school students who learned mathematics out-of-class using the cellular phone. The building of the learning community was led by three third year pre-service teachers majoring in mathematics and computers. The pre-service teachers selected thirty $8^{\text {th }}$ grade students to learn mathematics with the cellular phone and be part of a learning community experimenting with this learning. To analyze the building and development stages of the cellular phone learning community, two models of community building stages were used; first the team development model developed by Tuckman (1965), second the life cycle model of a virtual learning community developed by Garber (2004)._The research findings indicate that a learning community which is centered on a new technology has five 'life' phases of development: Pre-birth, birth, formation, performing, and maturity. Further, the research finding indicate that the norms that were encouraged by the preservice teachers who initiated the cellular phone learning community resulted in a community which developed, nourished and matured to be similar to a community of experienced applied mathematicians who use mathematical formulae to study everyday phenomena.
\end{abstract}

Index Terms-Cellular phone, mobile learning, mathematics, learning community, middle school students, preservice teachers

\section{INTRODUCTION}

\section{A. Mathematics mobile education}

Mobile and wireless devices, especially mobile phones, are increasingly common amongst the younger generation. This provides new possibilities, opportunities and challenges for the educational environment [3], especially for math. These possibilities, opportunities and challenges are examined in recent studies, for example [4] and [5] examined the use of mobile phones in learning mathematics amongst university pre-service teachers. Reference [5] studied learning processes and experiences within a mobile phone learning environment. In doing so they aimed to examine how socio-cultural and situated learning aspects were reflected in these processes and experiences. They found that the contribution of the mobile phone environment "lies not only in making dynamic mathematical application more available, but also in supporting the execution of tasks that are closer to the students' experiences and more relevant to them, which has the potential to enhance experiential learning. Further, the authors reported that the participants' learning experiences motivated their further learning.

Reference [6] examined the perceptions of middle school students regarding the use of cellular phone midlets and web applets in learning mathematics and how they differentiated between the two technological tools. Reference [6] reported that the students were aware of the different aspects of the tools, and paid attention to their following characteristics: their availability, their portability, the collaborative aspect of using them, their communicative aspect, the size of their interface, and their usability. The students used these aspects to describe their experience with the tools in learning mathematics, to differentiate between them, and to decide which tool they would use in their future learning and how they would use each tool. For example the students said they would use the web applets in their future learning because there are more applets than midlets that involve mathematical topics. A higher percent of students preferred the cellular phone as a learning tool because of its portability and communicability.

Reference [7] examined the perceptions of middle school students regarding using the cellular phone to learn mathematics by carrying out authentic activities out-ofthe-classroom. They found that what encouraged the students to participate in the new learning experience were the novelty of the experience and the use of the cellular phone. On the other side, the students perceived the following characteristics of carrying out authentic activities out-of-the-classroom to learn mathematics using the cellular phone: (1) learning mathematics independently, (2) learning mathematics collaboratively and with equal relations with their teachers (3) learning mathematics in a humanistic environment, (4) learning the mathematics of real world phenomena, (5) learning visual mathematics, (6) performing different mathematical tasks, (7) learning mathematics easily and effectively.

Reference [8] examined the conditions that influence the middle school learning of mathematics using the cellular phone, and, at the same time, the consequences of such learning. They found that what affected the students' learning in the cellular phone environment were: (1) the characteristics and technologies of the cellular phone like its portability and built-in camera, (2) the mathematical activities requirements and topics, (3) the learning setting (inside or outside the classroom), (4) the intention of the researchers who participated in the teaching processes, (5) the involvement of the school principal and the coordinating teacher. The consequences of the mathematics learning in the cellular phone environment were: (1) the students connected mathematics with real life, and (2) the students developed a new approach to mathematics where 
they looked at it as applied science. Further, the authors reported that during the carrying out of the activities the students (1) were in control of their learning and worked as applied mathematicians (examining a phenomenon and relating mathematical formulae to it).

\section{B. What is a learning community?}

Reference [9] describes learning communities as "collections of individuals who are bound together by natural will and a set of shared ideas and ideals". The authors add that communities depend on autonomous and independent individuals who influence each other within the learning process. Reference [10], as reported by [11], says that the word community implies both a meaning and a feeling. Bauman mentions understanding, common values, belonging, engagement, considerations and the collaboration between the members as some of the characteristics of a community.

Reference [12] says that most communities, whether online or traditional, share a number of qualities and characteristics: Communities are held together by distinct operating norms, members are distinguished by their formal and informal roles, trust must be built to ensure quality interactions, and a shared sense of purpose serves as the glue that bonds the community together. Regarding learning communities, Kaplan stresses that they must possess the previously mentioned characteristics and further engage people in learning processes over time.

Reference [13] distinguishes between a learning environment and a learning community, saying that a learning environment is not necessarily a learning community. Reference [13] stresses that "for a community to emerge, a learning environment must allow learners to engage each other intentionally and collectively in the transaction or transformation of knowledge", so individuals, in a learning community should take advantage and initiate processes for engaging ideas, negotiating meaning and learning collectively.

Reference [14], depending on the literature, points at essential steps to ensure creating and maintaining a community. These steps include: creating value, facilitation, establishing operating norms, creating an environment of trust, supporting individuality, and empowerment. These steps are described in Table 1 below as in [14].

\section{The life cycle of communities: A model of group development}

Reference [1] describes a model of group development that consists of four stages: forming, storming, norming and performing. Reference [15] added a fifth stage: adjourning. These stages are described below depending on [1] and [15].

Forming: Groups initially start through orientation that is accomplished primarily through a testing that serves to identify the boundaries of both interpersonal and task behaviors. At the same time, dependency relationships with leaders, other group members, or pre-existing standards are established. So, the group process of forming consists of orientation, testing and dependence.

Storming: The second stage is characterized by conflict and polarization around interpersonal issues, with concomitant emotional responding in the task sphere. These behaviors serve to resist group influence and task requirements.
TABLE I.

STEPS TO ENSURE THE CREATION AND MAINTENANCE OF A COMMUNITY

\begin{tabular}{|c|l|}
\hline Steps & \multicolumn{1}{c|}{ Description } \\
\hline Creating Value & $\begin{array}{l}\text { Establishing good relationships amongst the stu- } \\
\text { dent group. } \\
\text { Using group techniques to foster healthy and } \\
\text { meaningful discussion. } \\
\text { Ensuring that appropriate spaces are established } \\
\text { for work. }\end{array}$ \\
\hline Facilitation & $\begin{array}{l}\text { To enable facilitation, the coordinator should be } \\
\text { able to connect with community members on a } \\
\text { human level. }\end{array}$ \\
\hline $\begin{array}{c}\text { Establishing } \\
\text { operating norms }\end{array}$ & $\begin{array}{l}\text { Establishing operating norms helps the participants } \\
\text { know how to behave and what to expect. }\end{array}$ \\
\hline $\begin{array}{c}\text { Creating an } \\
\text { environment of } \\
\text { trust }\end{array}$ & $\begin{array}{l}\text { Techniques for developing trust include involving } \\
\text { all participants in the development of shared ex- } \\
\text { pectation and the development of operating norms. } \\
\text { They also include ensuring that people have the } \\
\text { opportunity to get know each other and feel com- } \\
\text { fortable communicating with each other. }\end{array}$ \\
\hline $\begin{array}{c}\text { Supporting indi- } \\
\text { viduality, and } \\
\text { empowerment }\end{array}$ & $\begin{array}{l}\text { Supporting individuality and empowering commu- } \\
\text { nity members maintain a community. }\end{array}$ \\
\hline
\end{tabular}

Norming: In the third stage, resistance is overcome by in-group feeling and cohesiveness, new standards evolve, and new roles are adopted. In the task realm, intimate, personal opinions are expressed.

Performing: In the fourth stage, roles become flexible and functional, and group energy is channeled into the task. Structural issues have been resolved, so structure can now become supportive of task performance.

Adjourning: The fifth stage involves dissolution of the community and entails bringing closure to the project on which the community is based. The process can be stressful, particularly where the dissolution is unplanned

\section{The life cycle of a virtual learning community:}

Reference [2] describes the stages of the life cycle of a virtual learning community:

Pre-birth: This stage occurs when the development, software, and policies of the community are established. Garber said that, in academic contexts, the elements of this stage are generally established before the community is formed.

Formative: During the formative stage, new members are brought into the community and the community's identity develops. Reference [16] described this stage as the one at which new acquaintances are made, similarities between members are identified, and communication is recurrent. Reference [17] said that at this stage the community needs nurturing to develop the community's identity.

Maturity: This stage occurs when the community begins to function independently of direct guidance. Reference [13] identified this stage as the one at which the purpose, shape, and operations of the community have been settled, and there is a less central role for the facilitator. Reference [16] pointed that at this stage camaraderie may be established through long-term and/ or intense associations.

Metamorphosis: This stage occurs when the community becomes something that it originally was not. Some 
members may resist this change and attempt to prevent it. Reference [18] says that for some communities, a natural decline, leading to death, may be a best option for the community at this stage. This could be so to enable active members of the community to join or initiate new communities which are still nourishing.

Death: This is the final stage of a virtual learning community, when members leave, discussion slows to the point that there is not enough participation to motivate them to return, and/ or the community has served its purpose. The death of an online community may be natural, as for example at the end of an online course, or unnatural, as when a high authority forces a community to break up.

\section{E. The research rationale}

Reference [19] pointed at the advantages of building learning community for students, saying that research provides evidence that strong feelings of community may not only increase participation, but also the flow of information among all learners, availability of support, commitment to group goals, cooperation among members, and satisfaction with group efforts. Reference [20] found that building a virtual 'artificial intelligence' enabled an Algebra learning community to sustain active participation of students and teachers, and to intensify their communication and interaction. Reference [21] pointed at the importance of building learning communities at schools, saying that learning communities do not merely represent congeniality, but rather dig deeply into learning. Reference [21] added that learning communities engage school students in disciplined inquiry and continuous improvement in order to "raise the bar" and "close the gap" of student learning and achievement.

Reference [22] indicates that it is necessary to create learning communities when given the task of teaching students new technologies. This is the case in the current research, where the preservice teachers built a students' learning community to make the students use the cellular phone as a new technology for learning mathematics.

Little research has been done about building learning communities that learn mathematics with the cellular phone. This research attempts to examine how such a community developed and the phases it went through. This will give teachers an idea how to build a successful mathematics leaning communities; using technological tools, and what to expect in doing so.

\section{F. Research question}

What are the stages of building a mathematics learning community that evolves in a cellular phone environment and which is characterized by solving authentic problems?

\section{RESEARCH METHODOLOGY:}

\section{A. Research setting and sample}

The experiment took place in an Arab middle school in Israel. It was led by three third year pre-service teachers majoring in mathematics and computers. The pre-service teachers were part in the year before of a project led by their mentor and the writer of this article, and which integrated the cellular phone in teaching and learning the function topic which is part of the mathematics curriculum of grade nine. These pre-service teachers participated in preparing activities appropriate for learning mathematics with the cellular phone and in directing the students when carrying the activities. The three pre-service teachers carried out the experiment as their final project in the mathematics didactics course.

They selected thirty 8 th grade students to participate in the project. The selection was done on the basis of volunteering from the side of the students and the ownership of appropriate cellular phones. All the learning was done by carrying out outdoor activities that involved exploring the mathematics of real life phenomena. The students utilized the various characteristics and technologies of the cellular phone to do such exploration (its portability, its camera, its stopper, its midlets, etc.).

At the beginning, the students carried out activities suggested by the preservice teachers. Later in the experiment, when they had carried out the real world activities suggested by the students, the students started to develop activities themselves. They did that by suggesting real world activities that they judged to be executable with cellular phones. The students usually started from a specific suggestion and developed it further till they considered the activity to be worth carrying out. All the activities are described below.

\section{B. The Mathematical Software}

The middle school students worked with cellular phone software (midlets) which support the learning of algebra and geometry. In order to perform the activities assigned to them, the students were required to use the algebraic midlets and various tools and technologies embedded in their cellular phones. The participants used the midlet "Fit2Go" which enables the user to draw specified points that fit a mathematical problem and then to fit a linear or a quadratic function for them.

The students downloaded the midlets from 'Math4Mobile' site [23] with the help of each other and the help of the preservice teachers. They used one of three methods to do that: (1) they went to the Math4Mobile site directly from their phones and downloaded the midlets (2) they downloaded the midlets to their computers and then used the phone's connectivity software and a cable or an infra-red link to copy the downloaded midlets to their phones (3) they received the downloaded midlet courtesy of another student via Bluetooth.

Multipliers can be especially confusing. Write "Magnetization $(\mathrm{kA} / \mathrm{m})$ " or "Magnetization $\left(10^{3} \mathrm{~A} / \mathrm{m}\right)$." Figure labels should be legible, about 10-point type.

\section{Activities}

At the beginning, the preservice teachers required the students to carry out specific real world activities. The activities suggested by the preservice teachers were:

1. Finding the relation between the weight and the height of the members of a group.

2. Finding the relation between the number of sons and the number of daughters in families.

3. Finding the relation between the circumference of the trunk of a tree and the circumference of one of its branches.

4. Finding the relation between the radius of car's tyres and its height.

5. Finding the relation between the time of filling a container and the height of the water in it. The stu- 
dents worked with different shapes of containers, one at a time.

6. Finding the relation between the height of a person and his/her running speed.

7. Finding the relation between the time that passes starting from the throwing of a ball and the distance that this ball passes until it halts.

8. Finding the relation between the weight of a person and the number of fingers in his/her hand. This activity was given to introduce the constant function to the students.

After the students carried out the activities suggested by the preservice teachers, they were requested to suggest by themselves authentic activities that they could carry out with cellular phones. The activities suggested by the students were:

1. Finding the relation between the temperature of the water in a container and the time required for a cube of ice to melt in that water.

2. Finding the relation between the circumference of a rock and its height.

3. Finding the relation between the length of a tree leaf and its width.

4. Finding the relation between the height of a person and the width of his/her step.

5. Finding the relation between the time that elapses from planting a plant and the plant's height.

6. Finding the relation between the time elapsing from the moment of lighting a candle and its height.

\section{Data collecting tools}

The preservice teachers used various means to collect data regarding the participants' learning of mathematics with cellular phones: observations, videoing, blogwriting and interviews.

The current research used all the data that the preservice teachers collected to analyze the students' building of mathematical knowledge when solving authentic problems using the cellular phone. In addition, the current research used additional data: diaries that the preservice teachers were requested to keep, so that they can reflect on the flowing of their experiment.

\section{E. Data analysis}

Coding the learning community building stages:

To determine the learning community building stages, I used the previously mentioned two models of community building stages; first the team development model developed by [1], and second the life cycle model of a virtual learning community developed by [2].

\section{$F$. The relevance of the data analysis to the setting and theme of the research}

The goal of this research was finding the stages of building a learning community of middle school students who solve authentic problems in a cellular phone environment. Regarding the stages of building a learning community, [24] used the model in [1] to examine the emergence of virtual teams in the business world. Reference [25] used the same model to examine the stages of students' group development in university setting. Regarding the use of the model in [2] to examine the develop- ment of the cellular phone mathematics learning community, it hasn't been used empirically in many researches, if any, but it suits the intention to examine the building development of the cellular phone learning community for it came to address similar phenomena.

\section{FINDINGS}

The cellular phone learning community described here went through the following stages when carrying out outdoor mathematics activities.

\section{A. The building phases of cellular phone mathematics} learning community:

1) First phase: Pre-birth

This phase consisted of three stages:

\section{Stage 1: Design of technology}

The first stage was the design and development carried out by university designers of a cellular phone environment for the learning of mathematics. In our case, this environment was Math4Mobile.

Stage 2: Spreading the news about the technology

This stage consisted of the following: the university developers spread news about their new learning environment to their colleagues and fellows. One of these colleagues and fellows was a pedagogic mentor in a teacher training college who decided to try the new technology in the training schools where his preservice teachers practice teaching mathematics.

Stage 3: Participating in an experiment which utilizes new technology for teaching and learning

The pre-service teachers participated as students in an experiment in which their mentors used the cellular phone technology in teaching mathematics for grade nine in the training schools.

Examples from the preservice teachers' writing on this stage, as written in their diaries and which describe the preservice teachers' thoughts and wondering at this stage (translated from Arabic):

Preservice teacher: I wondered at the beginning whether the cellular phone would be an efficient tool in teaching mathematics.

Preservice teacher: The students had fun learning mathematics with the cellular phone.

Preservice teacher: the mathematics teacher started to take interest in the cellular phone after few lessons, and she expressed her idea that using the cellular phone would motivate students to learn mathematics.

\section{2) Second phase: birth}

This phase consists of two stages:

Stage 1: Deciding to use the technology in a project and research

The first stage of birth happened when the pre-service teachers decided to carry out a project concerned with learning mathematics in a cellular phone environment, so that they could research some aspects of its use in the mathematics classroom.

Examples from the preservice teachers' writing on this stage:

Preservice teacher: Watching our pedagogic mentor teach mathematics to middle school students with the cel- 
lular phone encouraged me to try teaching the same way myself.

Preservice teacher: When I saw that Suma (a pseudonym) decided to research how teaching the functions topic with the cellular phone would benefit grade eight students cognitively I decided to join her and examine how such teaching would benefit the affective aspect of learning.

Stage 2: management issues

The second stage of birth consisted of the following: contacting a school principal to make an agreement regarding the use of cellular phones in a mathematics classroom, and arranging with the mathematics teachers in the school regarding the students who would participate in the project.

Examples from the preservice teachers' writing on this stage:

Preservice teacher: One of the mathematics teachers didn't cooperate with us, saying that cellular phones are not for learning, but the mathematics coordinator in the school encouraged eight grade students to join our project.

\section{3) Third phase: Formation}

This phase consisted of two stages:

Stage 1: Wondering, answers and expectations

The first stage of the formation phase, which occurred in the experiment described here, consisted of the following happenings: some students volunteered to join the project, but part of them were not satisfied with this decision, the preservice teachers met student volunteer and presented the project to them, the students wondered about the nature of the project and asked questions which the preservice teachers answered. The students developed some expectations from the project.

Examples from the students' writing on this sub-phase:

Student: I hesitated if to join the project because I didn't want to learn more mathematics.

Student: I wondered how the cellular phone could be used for learning mathematics, for I knew it's only good for music, fun and communication.

Student: According to the teachers' description, this learning is going to be fun.

Examples from the preservice teachers' writing on this sub-phase:

Preservice teacher: the students had a lot of questions regarding the new project. We assured them everything was going to be all right. They didn't seem to believe us one hundred percent, but it was obvious that our answers encouraged them to stay in the project.

Stage 2: Setting the stage technologically for learning and beginning the community dynamics

The second stage of the formation phase, which occurred in our case, consisted of the following happenings: (1) The students had some difficulty downloading the midlets to their cellular phone, but with the help of the preservice teachers and the help of each other, they succeeded to download the midlets to their cellular phones. (2) The students got themselves familiar with the new environment.

Examples from the students' writing on this sub-phase:

Student: I found difficulty downloading the midlet to my cellular phone, but the teacher showed me how.
Student: I sent the midlet to other students using my Bluetooth.

Examples from the preservice teachers' writing on this sub-phase:

Preservice teacher: It was wonderful to watch the students help each other to download the midlets. This student collaboration made our interference unneeded.

\section{4) Fourth phase: Performing and norming}

The performing phase, which occurred in our case, consisted of the following: (1) the students performed the outdoor activities on their own, deciding how to perform the activity and which task every member of the group will perform; (2) During this performing of outdoor activities, the students got to know each other and to know the preservice teachers; the students turned to the preservice teachers for solutions to all of their problems, and the students got to know that the preservice teachers are but advisors to them but not the source of knowledge; and (3) They found learning mathematics outdoors with the cellular phone to be fun

Examples from the students' writing on this phase:

Student: at the beginning, we discussed how to carry out the activity, and then everyone chose which task to do. These steps are so important for they prepare for the following tasks.

Student: What astonished me is the collaboration between us and our teachers. This collaboration was on equal terms; unlike the situation in our school.

Student: the teachers directed us how to carry out the experiment by ourselves.

Examples from the preservice teachers' writing on this phase:

Preservice teacher: the students seemed dependent on us at the beginning, but we didn't give answers for them, only directions or leading questions. Gradually, the students learned to depend on themselves in carrying out the activities.

\section{5) Fifth phase: Maturity}

The maturity phase, which occurred in our case, consisted of the following happenings: (1) the students got more confident of themselves and gradually got less dependant on the preservice teachers (2) the students started on their own to suggest mathematical activities that could be carried outdoors with the help of cellular phones.

Examples from the students' writing on this phase:

Student: We enjoyed suggesting outdoor activities to carry out with cellular phone. We felt that we are teachers and students at the same time. We were happy when the teachers liked our activities.

Examples from the preservice teachers' writing on this phase:

Preservice teacher: It astonished us that the students started to suggest interesting activities to study using the cellular phone. In a way, this made us feel that our presence was unnecessary.

\section{DISCUSSION:}

Development phases of the cellular phone mathematics learning community:

Reference [26] says that the growth of the community depends on the emergence of new issues to be discussed 
or on setting new challenges for the community. This is true generally, but specifically the beginning of the cellular learning community described here was the emergence of new mathematical software for the cellular phone. The cellular phone would not have become a learning tool for mathematics, especially linear and quadratic functions, if it had not included a mathematical software component, in our case midlets.

The cellular mathematics learning community described here had five 'life' phases of development: Prebirth, birth, formation, performing, and maturity. Reference [15] identified four 'life' phases of a learning community: forming, storming, norming and performing, while [2] identified three 'life' phases of learning community: pre-birth, formation and maturity. The third phase of the cellular phone learning community consisted itself of two stages: first stage - wondering, answers and expectations, and the second stage - setting the stage for the learning technology and the beginning of the community dynamics. So, the development of this cellular learning community has common factors with other learning communities and specific factors which distinguish it from other communities, like the wondering sub-stage of the second stage of the formation phase. What is also specific for this community life development is that its maturity phase is characterized by an interesting educational phenomenon: the students turning into mathematicians who look for real life phenomena to investigate mathematically.

Let's now discuss every phase of the life cycle of the cellular phone learning community:

\section{A. The pre-birth phase:}

The pre-birth phase constituted of three stages that involve issues related to design, communication and previous use of the new technology which is the tool of learning in the community. Only one sub-phase - the design of technology - is necessary, while the other two are possible but not necessary. The preservice teachers could have come upon the technology by accident and decided to experience it in their training classrooms. The previous scenario is possible but far from being likely because probably preservice teachers are open to what they learn and witness, but not to what they come upon by chance. On the other hand, inservice teachers are more likely to take a decision to try a new technology in their classrooms because they are more independent and powerful regarding their teaching decisions than preservice teachers. though the sub-phases 'spreading the news by the academic faculty about the technology' and 'witnessing of the technology as tool for teaching and learning' by the learning community initiators' are not necessary, they speed the birth of the learning community and at the same time speed its subsequent life phases. Spreading the news about the new technology speeds the birth of the learning community because otherwise it may take the learning community initiators a long time to know about the technology, and this may delay their consideration to initiate it. On the other hand, witnessing the technology as tool for teaching and learning gives the learning community initiators a detailed picture of what could be done with the technology in teaching and learning, which helps the initiators in subsequent phases of the learning community's life, for example it helps them manage the project (an issue related to the birth phase), set the stage technologi- cally for learning and beginning the community dynamics (an issue related to the formation phase), or decide which learning roles of students to encourage (an issue related to the performing and norming phase).

\section{B. The birth phase:}

The birth phase constituted of two sub-phases: (1) Decision to use the technology in a project and as a subject for research (2) deciding how to manage the project. The two sub-phases are critical for the actual birth of the learning community because without any one of them no learning community would have come into life. One of the questions that could be asked regarding the first sub-phase is: what makes some preservice teachers decide to experiment teaching with a technology? Probably two issues are involved here: (1) witnessing a previous use of technology (2) the characteristics of the preservice teachers. The characteristics of the preservice teachers involve three aspects: (1) their tendency to use technology in their daily lives (2) their tendency to use technology in their teaching (3) their tendency to try new educational innovations in their teaching. This possible influence of the students' characteristics on their learning decisions is supported by the literature, for example [27] found that the characteristics of students influenced the efficacy of their face-toface and computer supported collaborative learning.

The development of the second-phase of the birth phase depends not only on the preservice teachers (the initiators of the learning community in our case), but also on school principals and mathematics teachers. A positive responsiveness from the side of a school principal and mathematics teachers would speed the formation of the learning community, while a negative responsiveness would slow that formation and probably frustrate the new technology adopters, in our case the preservice teachers.

\section{The formation phase:}

The formation phase constituted of two stages. The first stage was the first encounter between the students and the preservice teachers, but it was more critical for some students than for others because they needed to decide if to join the new experiment and the learning community. It was important for the preservice teachers at this stage to convince the hesitating students to join the new experiment and they succeeded to do that, probably because they themselves believed in the importance and advantages of using the cellular phones in teaching and learning mathematics. The second stage of the formation phase is the first encounter between the students and the new technology, in our case cellular phone midlets. The students overcame the difficulties they confronted in this first encounter by collaborating with the preservice teachers and with each other. This success of the students in their first encounter with the midlets' technology by collaborating agrees with the finding of [28] who reported that students found colleagues a valuable source of information when acquiring new technology skills. Reference [29] also reported that friends were a major source of information about new technologies. Talking about collaboration among the students, the second sub-phase was the beginning of collaboration in the learning community and the base on which further collaboration was done in subsequent phases. 


\section{Performing and norming phase:}

In the performing and norming phase, the students performed the learning activities in collaboration and on their own. Performing the learning activities, they needed to know their different roles in the learning community and the nature of the mutual relations between them and the preservice teachers and among themselves. In this phase, the students also got to know that the preservice teachers are not the source of knowledge but directors for them in their collaborative building of the mathematical knowledge. Thus the students' collaboration with the directing of the preservice teachers made the students' learning successful. This success in using technology in carrying out collaboratively learning activities is also reported by other researchers, for example [30] found that students' learning with technology was enhanced as a result of the collaboration and communication between the students who worked in pairs to study math and science.

\section{E. The maturity phase:}

In this phase the students matured as learners of mathematics and investigators of the mathematical aspects of real life phenomena. Thus they started to behave as applied mathematicians in the learning community; i.e. using mathematical theories and techniques to solve realworld problems. What could have influenced the students to become real mathematicians who want to research new real life phenomena is their appreciation of authentic learning experiences [29].

\section{CONCLusions:}

Reference [22] suggests learning communities as a tool which helps perform the task of teaching students new technologies. In this research, the preservice teaches' intention was not teaching new technologies but using new technologies to teach different mathematics outdoors, where the students take the responsibility on their learning. Doing so, they helped to build a learning community which flourished step by step going through life phases known in the life cycle of other social and leaning communities. The cellular learning community described here had five 'life' phases of development: Pre-birth, birth, formation, performing, and maturity. These are the phases of the life cycle of a learning community which lives a new experiment, in our case integrating the cellular phone in teaching mathematics outdoor. The described development of the cellular learning community has common factors with other learning communities and specific factors which distinguish it from other communities, like the wondering sub-stage of the second stage of the formation phase. What is also specific for the development of the community life is its maturity phase which is characterized by an interesting educational phenomenon: the students turning into mathematicians who look for real life phenomena to investigate mathematically.

This study supports the suggestion made by [31] that teachers should be flexible in the ways in which they present new technologies. The flexibility of the preservice teachers who initiated the cellular phone learning community resulted in a community which developed and matured to be more similar to a community of experienced mathematicians than to a community of middle school students who study mathematics depending on their teacher. It is important to note that this community worked with untraditional mathematics consisting of authentic activities outside the classroom. Thus the new technology represented by the cellular phone enabled new opportunities and learning contexts for the mathematics student. We can conclude that the mentioned new technology holds hope for mathematics learning and teaching.

\section{REFERENCES}

[1] Tuckman, B. W. (1965). Developmental sequence in small groups. Psychological Bulletin, 63, 384-399. The article was reprinted in Group Facilitation: A Research and Applications Journal, 3, 2001 and is available as a Word document: http://dennislearningcenter.osu.edu/references/GROUP\%20DEV\% 20ARTICLE.doc Accessed January 14, 2005.

[2] Garber, D. (2004). Growing virtual communities. International Review of Research in Open and Distance Learning. 5(2). Retrieved July 28, 2009, from_http://www.irrodl.org/content/ v5.2/technote $4 . h$ tml

[3] Cobcroft, R., Towers, S., Smith, J. and Bruns, A. (2006). Mobile learning in review: Opportunities and challenges for learners, teachers, and institutions. In Proceedings of Online Learning and Teaching (OLT) Conference 2006, 21-30, Queensland University of Technology, Brisbane. Retrieved May 09, 2009, from https:/olt.qut.edu.au/udf/OLT2006/gen/static/papers/Cobcroft_OL T2006 paper.pdf

[4] Botzer, G., \& Yerushalmy, M. (2007). Mobile applications for mobile learning. Proceedings for "Cognition \& Exploratory Learning in Digital Age" (CELDA), Algrave, Portugal.

[5] Genossar, S., Botzer, G., \& Yerushalmy, M. (2008). Learning with mobile technology: A Case Study with Students in Mathematics Education. Proceedings of the CHAIS conference, Open University.

[6] Daher, W. (2009). Students' Perceptions of learning mathematics with cellular phones and applets. International Journal of Emerging Technologies in learning, (1), 23-28. Retrieved July 28, 2010 from http://online-journals.org/i-jet/issue/view/51.

[7] Baya'a, N., \& Daher, W. (2009). Learning mathematics in an authentic mobile environment: the perceptions of students. International Journal of Interactive Mobile Technologies, 3 (Special Issue, IMCL 2009), 6-14.

[8] Baya'a, N., \& Daher, W. (2010). Middle school students' learning of mathematics using mobile phones: Conditions and consequences. Journal of Interactive Learning Research, 21(2), 165185. Chesapeake, VA: AACE.

[9] Kowch, E., \& Schwier, R. (1997). Characteristics of technologybased virtual learning communities. Retrieved July 28, 2010 from: http://www.usask.ca/education/coursework/802papers/communitie s/communities.htm

[10] Bauman, Z. (2001). Community - seeking safety in an insecure world. Cambridge: Polity.

[11] Carlén, U. (2005). Typology of online learning communities. International Journal of Web Based Communities. Retrieved July 30, 2010 from http://www.learnloop.org/olc/typologyOLC.pdf

[12] Kaplan, S (2002). Building communities - strategies for collaborative learning, Learning Circuits, American Society for Training \& Development. Retrieved July 30, 2010 from http://www.astd.org/ LC/2002/0802 kaplan.htm

[13] Schwier, R. (2002). Shaping the metaphor of community in online learning environments. Retrieved July 30, 2010 from http://cde.athabascau.ca/ISEC2002/papers/schwier.pdf

[14] Australian National Training Authority (2003). What are the conditions for and characteristics of effective online learning communities? (Version 1.00), Australian Flexible Learning Framework Quick Guides series. Retrieved July 30, 2010 from http://pre2005.flexiblelearning.net.au/guides/community.pdf

[15] Tuckman, B. W., \& Jensen, M. C. (1977). Stages of small group development revisited. Group and Organizational Studies, 2, 419427.

[16] Brown, R. (2001). The process of community-building in distance learning classes. Journal of Asynchronous Learning Networks 5(2).18-34. 
[17] Preece, J. (2000). Online communities: Designing usability, supporting sociability. Chichester, UK.: Wiley.

[18] Schwier, R.A. (2001). Catalysts, emphases and elements of virtual learning communities: Implications for research and practice. The Quarterly Review of Distance Education, 2(1), 5-18.

[19] Rovai, A. (2002). Building a sense of community at a distance. International Review of Research in Open and Distance Learning 3(1). Retrieved July 30, 2010 from http://www.irrodl.org/ 'index.php/irrodl/article/view/79/153

[20] Lee, F. L. (2001). Towards a virtual AI-enabled Algebra learning community. Paper presented in International Conference on Computers in Education, 2001, Seoul, Korea.

[21] Fullan, M. (2005). Learning communities writ large. In R. DuFour, R. Eaker, R. DuFour (Eds.), On Common Ground, 209-223. Bloomington, Indiana: National Education Service.

[22] Riel, M., \& Fulton, K. (2001). The role of technology in supporting learning communities. Phi Delta Kappan, 82(7), 518-523.

[23] Yerushalmy, M., Weizman, A. (2007). Math4Mobile mobile environment. The University of Haifa. Retrieved July 30, 2010 from http://www.math4mobile.com

[24] Matthews, J. and Gladstone, B. (2000). Extending the group: a strategy for virtual team formation." Industrial and Commercial Training, (32), 24-29.

[25] Runkel, P., Lawrence, M., Oldfield, S., Rider, M., \& Clark, C. (1971). Stages of group development: An empirical test of Tuckman's hypothesis. The Journal of Applied Behavioral Science, 7, (2), 180-193.

[26] Aceto, S., Dondi, C., \& Marzotto, P. (2010). Pedagogical innovation in new learning communities: An in-depth study of twelve online learning communities. Retrieved July 30, 2010 from http://ftp.jrc.es/EURdoc/JRC59474.pdf

[27] Solimeno, A.; Mebane, M.E.; Tomai, M. \& Francescato, D. (2008) The influence of students and teachers characteristics on the efficacy of face-to-face and computer supported collaborative learning. Computers \& Education, 51(1), 109-128.

[28] Jones, M. C., \& Berry, R. L. (2000). Knowledge about information technology - a cross-cultural comparison. Journal of Education for Business, 173-176.

[29] Dooling, J. O. (2000). What students want to learn about computers? Educational Leadership, 58 (2), 20-24.

[30] Venville, G.; Wallace, J.; Rennie, L. \& Malone J. (2000). Bridging the boundaries of compartmentalized knowledge: student learning in an integrated environment. Research in Science \& Technological Education, 18 (1), 23-35.

[31] Kuperstein, J., \& Gentile, C. (2001, October). Calling students back: using technology to support engaged learning. Retrieved October 15, 2010 from http://www.microsoft.com/education/ instruction/aritcles/miami_engage.asp

\section{AUTHORS}

W. Daher is with Al-Qasemi Academic College of Education, Baka, Israel \& An-Najah University, Nablus, Palestine.

Received October $12^{\text {th }}, 2010$. Published as resubmitted by the authors March $24^{\text {th }}, 2011$. 